\title{
Cranial and skeletal size in red foxes, Vulpes vulpes (Carnivora, Canidae) in areas with large variation in food abundance
}

\begin{abstract}
Jan Englund
ABSTRACT. Many skeletal parts vary in size between yearlings of different year-classes depending on the food situation at the foetal stage as well as during the first spring-autumn period in life. The difference between year-classes is more pronounced for certain parts of the cranium and mandibles. The reason is supposed to be that full size is less important for some parts of the skull and bones than for other parts. Foxes born in years with few rodents do not compensate the bad growth that year by further growth later in life. Several parts of the cranium and mandibles will continue to grow in adult foxes, at least during their second summer of life, if the food abundance is good enough. The zygomatic width and the distance between $\mathrm{C}$ and P1 in the mandibles most often continue to increase in size after the first year, even when food is scarce.
\end{abstract}

KEY WORDS: Vulpes vulpes, skeletal size, age, growth, food supply.

Jan Englund [je.fox@swipnet.se], Section of Vertebrate Zoology, Swedish Museum of Natural History, S-10405 Stockholm, Sweden.

\section{Размеры черепа и скелета у лисицы, Vulpes vulpes (Carnivora, Canidae) в районах с различной кормовой базой}

\section{Ян Энглунд}

\begin{abstract}
РЕЗЮМЕ. Исследованы особенности роста черепа и элементов скелета у лисиц (Vulpes vulpes), добытых в Швеции в 1966-1971 гг. Многие скелетные элементы варьируют в размерах у сеголеток разных возрастных классов в зависимости от кормовой базы в течение эмбриональной стадии и весенне-осеннего периода первого года жизни. Различия между возрастными группами особенно заметны в размерах некоторых частей черепа и нижней челюсти. Предполагается, что достижение полного размера не одинаково важно для различных частей черепа и костей. Лисицы, рожденные в годы с небольшой численностью грызунов, не компенсируют недостатки роста в дальнейшие годы. У взрослых лисиц некоторые отделы черепа и нижней челюсти продолжают увеличиваться, по крайней мере, в течение второго года жизни при достаточном обилии кормовых ресурсов. Обычно скуловая ширина и расстояние между клыком и первым премоляром в нижней челюсти продолжают увеличиваться в размерах после первого года даже когда кормовых ресурсов недостаточно.
\end{abstract}

КЛЮЧЕВЫЕ СЛОВА: Vulpes vulpes, скелет, возраст, рост, пищевые ресурсы.

\section{Introduction}

Different parts of the cranium and mandibles grow after the first year of life among foxes living in areas with a high food production (Huson \& Page 1980; Lüps, 1974; Hell et al., 1989; Englund, 2006).

According to Lindström (1983) the mandibles in subadult females born in the southern parts of the coniferous belt in Sweden cease to grow in NovemberDecember. However, vixens born in years when food is scarce will not be full-grown at that time. Lindström believes that these foxes will compensate for that by further growth later in life.

Yom-Tov et al. (2003) showed that the zygomatic breath, the length of the upper fourth premolar (P4) and the diameter of the canine, but not the greatest length of the skull, increased significantly during the twentieth century in Danish foxes. This change is supposed to have been caused by the improved food situation in Denmark during that time. If the change in size was caused by better growth of the young animals due to food increase or by a change in selection in favor of larger animals that can handle larger prey is not known.

The present study is based on material from the coniferous belt in northern Sweden, where the number of rodents fluctuates heavily from year to year (Englund, 1970; Hörnfelt, 1991, 1994). Furthermore, there are few food alternatives in these areas that can compensate for the rodents when these are scarce (Englund, 1965). In such years only few vixens will get any cubs and the mean litter size is only about half compared with peak years. And the mortality rate in spring and early summer is as high as $70 \%$ among the cubs, compared with about a $10 \%$ mortality when rodents are common (Englund, 1970, 1980). 
What effect may such a variation in food abundance have on the ability for foxes to grow? Will individual foxes born in certain years grow larger than foxes born in other years? And secondly, do foxes from all yearclasses grow in size during several years as shown for foxes in southern Sweden, or does further growth only occur for foxes born when rodents are scarce, a so called compensatory growth?

\section{Material and methods}

The present paper is based on data from skulls, mandibles and long bones from nearly 2500 foxes out of which more than 2400 were collected during the years 1966 through 1971. All are from the counties of Jämtland and Härjedalen in the northern part of the coniferous belt in Sweden (62-65 $\mathrm{N}$ latitude).

Most foxes were caught in steel traps in January through March. Very few were collected from other parts of the year. The material was delivered from approximately the same hunters and trappers all years and also from the same areas. Possible sampling errors therefore are supposed not to spoil the comparisons between year-classes.

Because material was collected from trappers often long bones were missing or parts of the skeleton were destroyed. The skeletal parts were simmered for several hours in water with domestic detergent before cleaning.

Juveniles were distinguished from older foxes when possible by open sutures in the tibia or by the presence of an open suture between the basioccipital and basisphenoid bones in the cranium (Churcher, 1960). Other foxes were aged by the incremental annuli in the tooth cementum of the canines. The technique used was that described by Jensen and Nielsen (1968) and modified by Englund (1970).

Foxes in Jämtland and Härjedalen are born about one month later than foxes in the southern counties (Lloyd \& Englund, 1973). The foxes in the south stop growing during November (Englund, 2006). When com- paring the size of the crania, mandibles and long bones from foxes of different year-classes, juveniles killed in December or earlier therefore are excluded here. However, data from the permanent teeth P4 and M3 of young foxes has been used irrespective of when the foxes were killed, even from those killed in early autumn.

Cranial measurements taken are as follow (the codes in parenthesis corresponds to those given in von den Driesch, 1976): greatest length (akrokranion-prosthion (1)); condylobasal length (2); palatal length (the median point of intersection of the line joining the deepest indentations of the choanae to the prosthion (13a)); greatest width of the braincase (29); mastoid width (23); zygomatic width (30); and length of the right upper tooth P4 (L).

Mandibular measurements are: total length (from infradentale to the midpoint of the condyle (1)); distance between the alveoli of the canine and the $\mathrm{p} 1$; length of p1-p4 (11) and of m1-m3 (10) both measured along the alveoli; thickness of the mandible below the middle of M1; and length of the crown of M1 (13).

Greatest length was measured on the humerus, the ulna, the radius and the tibia (GL). Femural length was measured from the superior surface of the femoral head to the most distal point of the bone (GLC), which for foxes is the greatest length in the femur.

Measurements were recorded to the nearest $0.1 \mathrm{~mm}$ using calipers connected to a computer (Billfors \& Jacobsen, 1974). Means and standard deviations for the different measurements, as well as the number of foxes measured are given in the Tables 1-9. The ages are given in years followed by week, during which the animals were killed, and a period expressed in the week numbers (0-53). T-test was used to compare the means of the different year-classes. The relationship between different measurements and age was analyzed quantitatively for each sex by regression analysis using SPSS/ $\mathrm{PC}+$. In all tests yearlings killed during their first calendar year are excluded.

Table 1. Some ecological data from the counties of Jämtland-Härjedalen, and the mean size in mm among foxes killed in January as yearlings or later in life. Standard deviations and the number of foxes examined are given in parentheses.

\begin{tabular}{|c|c|c|c|c|c|}
\hline & 1966 & 1967 & 1968 & 1969 & 1970 \\
\hline $\begin{array}{l}\text { Rodents / fox stomach } \\
\text { in January-April }\end{array}$ & $? ? ?$ & 1.6 & 0.1 & 0.5 & 1.2 \\
\hline $\begin{array}{l}\text { Rodent index in } \\
\text { spring-summer }\end{array}$ & +++ & - & + & ++ & $? ?$ \\
\hline Cubs born/vixen & $? ? ?$ & 3.9 & 0.8 & 2.5 & 3.7 \\
\hline Cub mortality (\%) & $? ? ?$ & 70 & 34 & 7 & 23 \\
\hline Male foxes born in & 1966 & 1967 & 1968 & 1969 & 1970 \\
\hline \multicolumn{6}{|l|}{ Cranium } \\
\hline Greatest length & $158.5(5.70 / 182)$ & $152.4(5.30 / 147)$ & $151.9(5.86 / 84)$ & $154.6(5.30 / 200)$ & $154.5(4.98 / 102)$ \\
\hline Condylobasal length & $152.1(5.39 / 164)$ & $146.1(4.67 / 128)$ & $145.4(5.53 / 76)$ & $148.4(4.97 / 174)$ & $148.4(4.26 / 85)$ \\
\hline
\end{tabular}


Table 1 (continuing).

\begin{tabular}{|c|c|c|c|c|c|}
\hline Male foxes born in & 1966 & 1967 & 1968 & 1969 & 1970 \\
\hline \multicolumn{6}{|l|}{ Cranium } \\
\hline Palatal length & $78.9(3.20 / 233)$ & $75.4(3.03 / 212)$ & $75.0(3.24 / 102)$ & $76.5(3.09 / 262)$ & $76.6(2.88 / 134)$ \\
\hline Braincase width & $49.3(1.29 / 173)$ & $48.6(1.39 / 129)$ & $48.5(1.45 / 78)$ & $48.8(1.28 / 181)$ & $48.7(1.37 / 96)$ \\
\hline Mastoid width & $49.1(1.54 / 179)$ & $48.3(1.39 / 136)$ & $47.9(1.64 / 84)$ & $48.3(1.36 / 187)$ & $48.6(1.34 / 100)$ \\
\hline Zygomatic width & $82.8(2.72 / 157)$ & $80.7(2.75 / 125)$ & $80.3(3.33 / 59)$ & $80.3(2.59 / 153)$ & $79.5(2.46 / 68)$ \\
\hline P4 length & $14.5(0.63 / 201)$ & $14.3(0.59 / 229)$ & $14.4(0.59 / 126)$ & $14.4(0.65 / 365)$ & $14.3(0.62 / 232)$ \\
\hline \multicolumn{6}{|l|}{ Mandible } \\
\hline Total length & $117.4(4.08 / 189)$ & $112.1(4.12 / 201)$ & $112.3(4.06 / 91)$ & $114.1(4.07 / 257)$ & $114.2(3.85 / 140)$ \\
\hline $\mathrm{c}-\mathrm{p} 1$ & $5.4(1.03 / 181)$ & $4.4(0.97 / 199)$ & $4.0(1.05 / 92)$ & $4.4(0.98 / 254)$ & $3.9(0.82 / 138)$ \\
\hline $\mathrm{p} 1-\mathrm{p} 4$ & $36.1(1.46 / 180)$ & $34.4(1.68 / 199)$ & $34.5(1.54 / 92)$ & $35.2(1.63 / 253)$ & $35.1(1.44 / 138)$ \\
\hline $\mathrm{m} 1-\mathrm{m} 3$ & $27.7(1.08 / 178)$ & $27.4(1.15 / 195)$ & $27.6(1.01 / 88)$ & $27.7(1.00 / 242)$ & $27.5(0.97 / 129)$ \\
\hline $\mathrm{m} 1$ length & $16.7(0.75 / 168)$ & $16.6(0.71 / 209)$ & $16.5(0.72 / 122)$ & $16.7(0.71 / 352)$ & $16.4(0.80 / 225)$ \\
\hline Thickness & $7.3(0.50 / 190)$ & $7.1(0.46 / 201)$ & $7.1(0.44 / 91)$ & $7.1(0.45 / 255)$ & $6.9(0.46 / 138)$ \\
\hline \multicolumn{6}{|l|}{ Long bones } \\
\hline Humerus & $138.9(5.34 / 132)$ & $135.2(4.97 / 123)$ & $134.2(4.85 / 63)$ & $137.0(5.29 / 168)$ & $137.6(4.63 / 79)$ \\
\hline Ulna & $153.2(5.50 / 182)$ & $149.8(5.32 / 155)$ & $148.9(5.62 / 70)$ & $151.7(5.08 / 206)$ & $152.1(5.09 / 90)$ \\
\hline Radius & $130.6(4.72 / 183)$ & $127.8(4.79 / 178)$ & $127.0(4.68 / 86)$ & $129.2(4.76 / 228)$ & $129.6(4.37 / 104)$ \\
\hline Femur & $146.4(5.67 / 106)$ & $141.4(5.65 / 77)$ & $142.8(5.67 / 68)$ & $144.9(5.51 / 175)$ & $144.1(4.29 / 83)$ \\
\hline Tibia & $160.1(6.58 / 141)$ & $155.6(6.46 / 107)$ & $156.2(6.40 / 89)$ & $158.9(6.39 / 239)$ & $158.0(6.01 / 128)$ \\
\hline Vixens born in & 1966 & 1967 & 1968 & 1969 & 1970 \\
\hline \multicolumn{6}{|l|}{ Cranium } \\
\hline Greatest length & $149.5(4.23 / 153)$ & $145.1(4.66 / 104)$ & $144.4(4.80 / 54)$ & $146.6(5.10 / 131)$ & $146.7(4.48 / 84)$ \\
\hline Condylobasal length & $143.9(4.31 / 135)$ & $139.2(4.34 / 94)$ & $138.4(4.45 / 55)$ & $141.1(4.89 / 117)$ & $141.4(4.23 / 77)$ \\
\hline Palatal length & $74.5(2.54 / 201)$ & $72.1(2.87 / 154)$ & $71.5(2.79 / 72)$ & $73.0(2.99 / 179)$ & $72.9(2.55 / 101)$ \\
\hline Braincase width & $48.0(1.08 / 140)$ & $47.6(1.20 / 98)$ & $47.3(1.20 / 52)$ & $47.7(1.24 / 115)$ & $47.7(1.28 / 85)$ \\
\hline Mastoid width & $47.3(1.18 / 145)$ & $46.6(1.32 / 106)$ & $46.2(1.30 / 55)$ & $46.6(1.33 / 120)$ & $46.7(1.28 / 89)$ \\
\hline Zygomatic width & $77.9(2.24 / 132)$ & $76.5(2.53 / 101)$ & $76.0(2.57 / 44)$ & $75.3(2.46 / 115)$ & $74.7(2.20 / 65)$ \\
\hline P4 length & $13.9(0.53 / 189)$ & $13.7(0.50 / 157)$ & $13.7(0.56 / 79)$ & $13.8(0.59 / 264)$ & $13.6(0.58 / 170)$ \\
\hline \multicolumn{6}{|l|}{ Mandible } \\
\hline Total length & $110.8(3.40 / 161)$ & $106.4(3.63 / 151)$ & $106.2(3.78 / 78)$ & $108.1(3.98 / 175)$ & $108.1(3.26 / 107)$ \\
\hline $\mathrm{c}-\mathrm{p} 1$ & $4.9(0.86 / 159)$ & $4.0(0.99 / 151)$ & $3.7(0.93 / 79)$ & $4.1(0.86 / 174)$ & $3.7(0.90 / 113)$ \\
\hline $\mathrm{p} 1-\mathrm{p} 4$ & $34.4(1.35 / 157)$ & $33.1(1.60 / 152)$ & $32.9(1.37 / 79)$ & $33.8(1.48 / 173)$ & $33.6(1.32 / 112)$ \\
\hline $\mathrm{m} 1-\mathrm{m} 3$ & $26.9(0.99 / 160)$ & $26.6(0.99 / 150)$ & $26.7(0.92 / 75)$ & $26.9(1.03 / 170)$ & $26.6(0.94 / 109)$ \\
\hline $\mathrm{m} 1$ length & $16.1(0.68 / 151)$ & $15.9(0.68 / 149)$ & $15.8(0.63 / 78)$ & $16.0(0.67 / 248)$ & $15.7(0.67 / 173)$ \\
\hline Thickness & $6.9(0.44 / 164)$ & $6.8(0.39 / 155)$ & $6.8(0.47 / 78)$ & $6.8(0.41 / 175)$ & $6.6(0.38 / 110)$ \\
\hline \multicolumn{6}{|l|}{ Long bones } \\
\hline Humerus & $130.5(3.86 / 122)$ & $127.2(4.11 / 99)$ & $128.0(4.33 / 62)$ & $128.5(5.54 / 113)$ & $129.3(4.16 / 55)$ \\
\hline Ulna & $143.8(4.29 / 161)$ & $140.0(4.86 / 118)$ & $140.6(4.90 / 64)$ & $141.7(5.75 / 137)$ & $143.4(4.85 / 75)$ \\
\hline Radius & $122.7(3.67 / 170)$ & $119.7(4.05 / 131)$ & $120.0(4.38 / 65)$ & $121.0(4.99 / 154)$ & $122.3(4.57 / 79)$ \\
\hline Femur & $138.9(5.01 / 86)$ & $133.9(4.74 / 73)$ & $135.0(4.54 / 62)$ & $136.8(5.49 / 127)$ & $136.7(4.93 / 67)$ \\
\hline Tibia & $151.0(5.17 / 117)$ & $146.1(5.55 / 93)$ & $147.3(5.43 / 73)$ & $148.7(6.38 / 170)$ & $149.4(6.11 / 87)$ \\
\hline
\end{tabular}




\section{Results}

Out of the five year-classes 1966 through 1970 , foxes born in 1966 had larger skulls, jaws and long bones than foxes born the other years. Those born in 1967 and 1968 were of about equal size. Foxes from 1969 and 1970 were somewhat larger than those from 1967 and 1968, but did not differ very much from each other (Tabs. 1 and 2).

\section{Foxes born in 1966}

Five length measurements (the two lengths of the cranium, the palatale, the mandibles and p1-p4) were for both sexes significantly larger than they were in foxes born in 1967 or 1968 (20 paired comparisons; 5 measurements $* 2$ year-classes $* 2$ sexes). In 15 of these comparisons, the differences were as large as 4.0 to $5.2 \%$. For the same five length variables foxes born in 1966 were 1.8 to $3.1 \%$ larger than those from 1969 or 1970 (Tab. 2).

The corresponding figures for the zygomatic width and the thickness of the mandibles were most often 1.8 to $3.1 \%$ and 2.8 to $5.8 \%$ respectively.

The width of the braincase and the mastoid as well as the length of P4 in the upper jaw also varied but not in all paired comparisons and to a lesser degree. For these variables foxes born in 1966 were only 0.8 to $2.5 \%$ larger than those from 1967 and 1968, and 1.0 to $2.2 \%$ larger than those born in 1969 or 1970 .

The mean lengths of the long bones in foxes from 1966 were 2.0 to $3.7 \%$ larger than those born in 1967 or 1968 , and 1.0 to $1.6 \%$ longer than those from 1969 or 1970.

The greatest difference was found for the distance between $\mathrm{c}$ and $\mathrm{p} 1$ in the mandibles, or 23 to 35 and 20 to $38 \%$ respectively.

\section{Foxes born in 1967 or 1968}

Also the differences between foxes born in 1967 or 1968 at one hand and those from 1969 or 1970 on the other were significant at the $1 \%$ level for many of the variables. In most cases these two groups differed from each other from 1.4 to $2.3 \%$ for the length of the cranium, the palatale, p1-p4 and the length of the mandibles (Tab. 2). In 8 cases out of 16 the figures for the zygomatic width and the thickness of the mandibles differed with 1.5 to $3.0 \%$.

The width of the braincase and the mastoid and the length of P4 in the upper jaw only differed in one single case out of 24 paired comparisons $(3 * 4 * 2)$. The length

Table 2. Percentage difference between year-classes (males/females; only cases with a significant difference at the $1 \%$ level are given).

\begin{tabular}{|c|c|c|c|c|c|c|c|c|c|c|}
\hline Year born & $1966 / 67$ & $1966 / 68$ & $1966 / 69$ & $1966 / 70$ & $1967 / 68$ & $1967 / 69$ & $1967 / 70$ & $1968 / 69$ & $1968 / 70$ & $1969 / 70$ \\
\hline \multicolumn{11}{|l|}{ Cranium } \\
\hline Greatest length & $4.0 / 2.8$ & $4.3 / 3.5$ & $2.5 / 2.0$ & $2.6 / 1.9$ & $-1-$ & $-1.4 /-0.8$ & $-1.4 /-0.9$ & $-1.7 /-1.5$ & $-1.7 /-1.6$ & $-1-$ \\
\hline Condylobasal length & $4.1 / 3.4$ & $4.6 / 4.0$ & $2.5 / 2.0$ & $2.5 / 1.8$ & $-1-$ & $-1.5 /-1.3$ & $-1.5 /-1.6$ & $-2.0 /-1.9$ & $-2.0 /-2.1$ & $-1-$ \\
\hline Palatal length & $4.6 / 3.3$ & $5.2 / 4.2$ & $3.1 / 2.1$ & $3.0 / 2.2$ & $-1-$ & $-1.4 /-1.2$ & $-1.6 /-$ & $-2.0 /-2.1$ & $-2.1 /-1.9$ & $-1-$ \\
\hline Braincase width & $1.4 / 0.8$ & $1.6 / 1.5$ & $1.0 /-$ & $1.2 /-$ & $-1-$ & $-1-$ & $-1-$ & $-1-$ & $-1-$ & $-1-$ \\
\hline Mastoid width & $1.7 / 1.5$ & $2.5 / 2.4$ & $1.7 / 1.5$ & $1.0 / 1.3$ & $-1-$ & $-1-$ & $-1-$ & $-1-$ & $-1.4 /-$ & $-1-$ \\
\hline Zygomatic width & $2.6 / 1.8$ & $3.1 / 2.5$ & $3.1 / 3.5$ & $4.2 / 4.3$ & $-1-$ & $-/+1.6$ & $+1.5 /+2.4$ & $-1-$ & $-/+1.7$ & $-1-$ \\
\hline P4 length & $1.4 / 1.5$ & $-/ 1.5$ & $-1-$ & $1.4 / 2.2$ & $-1-$ & $-1-$ & $-1-$ & $-1-$ & $-1-$ & $-/ 1.5$ \\
\hline \multicolumn{11}{|l|}{ Mandible } \\
\hline Total length & $4.7 / 4.1$ & $4.5 / 4.3$ & $2.9 / 2.5$ & $2.8 / 2.5$ & $-1-$ & $-1.8 /-1.6$ & $-1.8 /-1.6$ & $-1.6 /-1.8$ & $-1.7 /-1.8$ & $-1-$ \\
\hline $\mathrm{c}-\mathrm{p} 1$ & $23 / 23$ & $35 / 34$ & $23 / 20$ & $38 / 32$ & $10 /-$ & $-1-$ & $+13 /-$ & $-9.1 /-9.8$ & $-1-$ & $13 / 11$ \\
\hline $\mathrm{p} 1-\mathrm{p} 4$ & $4.9 / 3.9$ & $4.6 / 4.6$ & $2.6 / 1.8$ & $2.8 / 2.4$ & $-1-$ & $-2.3 /-2.1$ & $-2.0 /-1.5$ & $-2.0 /-2.7$ & $-1.7 /-2.1$ & $-1-$ \\
\hline $\mathrm{m} 1-\mathrm{m} 3$ & $1.1 / 1.1$ & $-1-$ & $-1-$ & $-1-$ & $-1-$ & $-1.1 /-1.1$ & $-1-$ & $-1-$ & $-1-$ & $-1-$ \\
\hline $\mathrm{m} 1$ length & $-1-$ & $-/ 1.9$ & $-1-$ & $1.8 / 2.5$ & $-1-$ & $-1-$ & $+1.2 /+1.3$ & $-1.2 /-$ & $-1-$ & $1.8 / 1.9$ \\
\hline Thickness & $2.8 /-$ & $2.8 /-$ & $2.8 /-$ & $5.8 / 4.5$ & $-1-$ & $-1-$ & $+2.9 /+3.0$ & $-1-$ & $+2.9 /+3.0$ & $2.9 / 3.0$ \\
\hline \multicolumn{11}{|l|}{ Long bones } \\
\hline Humerus & $2.7 / 2.6$ & $3.5 / 2.0$ & $1.4 / 1.6$ & $-1-$ & $-1-$ & $-1.3 /-$ & $-1.7 /-1.6$ & $-2.0 /-$ & $-2.5 /-$ & $-1-$ \\
\hline Ulna & $2.3 / 2.7$ & $2.2 / 2.3$ & $1.0 / 1.5$ & $-1-$ & $-1-$ & $-1.3 /-$ & $-1.5 /-2.4$ & $-1.2 /-$ & $-1.4 /-2.0$ & $-1-$ \\
\hline Radius & $2.2 / 2.5$ & $2.8 / 2.3$ & $1.1 / 1.4$ & $-1-$ & $-1-$ & $-1.1 /-$ & $-1.4 /-2.1$ & $-1.7 /-$ & $-2.0 /-1.9$ & $-1-$ \\
\hline Femur & $3.5 / 3.7$ & $2.5 / 2.9$ & $1.0 / 1.5$ & $1.6 / 1.6$ & $-1-$ & $-2.4 /-2.1$ & $-1.9 /-2.0$ & $-1.4 /-$ & $-1-$ & $-1-$ \\
\hline Tibia & $2.9 / 3.4$ & $2.5 / 2.5$ & $-/ 1.5$ & $1.3 /-$ & $-1-$ & $-2.1 /-1.7$ & $-1.5 /-2.2$ & $-1.7 /-$ & $-1-$ & $-1-$ \\
\hline
\end{tabular}


of $\mathrm{m} 1-\mathrm{m} 3$ and $\mathrm{m} 1$ varied in 5 cases out of 16 between 1.1 and $1.3 \%$. In 3 cases out of 8 the distance between $\mathrm{c}$ and $\mathrm{p} 1$ in the mandibles differed with 9 to $13 \%$.

The long bones in foxes born in 1967 or 1968 were significantly shorter than among foxes born in the two years thereafter. The differences varied from 1.1 to $2.4 \%$ in 27 pairs out of 40 comparisons (Tabs. 1 and 2).

\section{Size versus food conditions}

To make it easier to see what happens when the food situation changes, I will change the order of the yearclasses. When comparing three groups of foxes, those born under extremely good conditions as in 1966 with those born in 1969 and 1970 when conditions were less good and with the foxes born under very bad conditions as in 1967 and 1968, the following is found.

The main reduction in growth rate that first takes place when resources decrease from a very good to a moderate condition, affects the length of the cranium (especially from the tip of the nose to P4 in the upper jaw) and the mandibles (a significant decrease in all paired comparisons, most often in the range of 2 to $3 \%$ change).

The width of the braincase and the mastoid is only slightly affected or 1.0 to $1.7 \%$ in 6 cases out of 8
(75\%). The conditions are the same for the long bones which were shortened no more than 1.0 to $1.6 \%$ in 12 cases out of $20(60 \%)$. The length of the upper P4, and $\mathrm{m} 1$ and $\mathrm{m} 1-\mathrm{m} 3$ in the mandibles was affected only in a few occasions or 4 times out of $12(33 \%)$.

When food resources are reduced to a minimum as in 1967 and 1968, the length of the cranium and the mandibles will be another 1 to $2 \%$ shorter (in 31 cases out of 32). And the long bones will be another 1 to $2 \%$ shorter in 27 cases out of $40(68 \%)$.

The width of the braincase and the mastoid, and the length of the upper P4, the lower M1 and M1-M3 on the other hand were reduced in size only in very few occasions.

\section{Size versus age}

There are very few yearlings born in 1966 in this material, as well as old foxes among the later yearclasses; especially those born in 1970 (Tabs. 4 and 5). In spite of these shortcomings it is clear that the zygomatic width and the distance between $\mathrm{c}$ and $\mathrm{p} 1$ in the mandibles do increase with age and that for both sexes (Tab. 3). The growth is most evident for foxes born in 1968.

Apart from the zygomatic width, the $\mathrm{c}-\mathrm{p} 1$ distance, and some few other variables in males from 1970, only

Table 3. The increase in mm/year among foxes from the counties of Jämtland and Härjedalen. Only changes with a significance at the $1 \%$ level are included here (in parentheses P-value $<$ ). Yearlings killed in their first calendar year are excluded.

\begin{tabular}{|c|c|c|c|c|c|}
\hline Male foxes born in & 1966 & 1967 & 1968 & 1969 & 1970 \\
\hline \multicolumn{6}{|l|}{ Cranium } \\
\hline Greatest length & - & - & $2.9(0.002)$ & - & - \\
\hline Condylobasal length & - & - & $2.3(0.010)$ & - & - \\
\hline Palatal length & - & - & $1.6(0.002)$ & - & - \\
\hline Zygomatic width & - & $1.5(0.001)$ & $2.7(0.001)$ & $2.1(0.001)$ & $1.2(0.004)$ \\
\hline \multicolumn{6}{|l|}{ Mandible } \\
\hline Total length & - & - & $2.6(0.001)$ & - & $1.8(0.004)$ \\
\hline $\mathrm{c}-\mathrm{p} 1$ & $0.2(0.008)$ & $0.5(0.001)$ & $0.9(0.001)$ & $0.5(0.001)$ & - \\
\hline $\mathrm{p} 1-\mathrm{p} 4$ & - & - & - & - & $1.3(.001)$ \\
\hline Thickness & - & - & - & - & $0.3(0.008)$ \\
\hline Vixens born in & 1966 & 1967 & 1968 & 1969 & 1970 \\
\hline \multicolumn{6}{|l|}{ Cranium } \\
\hline Greatest length & - & - & $2.6(0.008)$ & - & - \\
\hline Condylobasal length & - & - & $2.4(0.007)$ & - & - \\
\hline Palatal length & - & - & $1.4(0.010)$ & - & - \\
\hline Zygomatic width & - & $0.6(0.012)$ & $2.2(0.001)$ & $0.9(0.008)$ & - \\
\hline \multicolumn{6}{|l|}{ Mandible } \\
\hline Total length & - & - & $2.3(0.002)$ & - & - \\
\hline $\mathrm{c}-\mathrm{p} 1$ & - & $0.6(0.001)$ & $1.0(0.001)$ & $0.7(0.001)$ & - \\
\hline Thickness & - & - & $0.3(0.001)$ & - & - \\
\hline
\end{tabular}


Table 4. Age specific means of the condylobasal length in male foxes from the northern forest area in Sweden. Ages are given as years and the week numbers during which the foxes were killed. Means in $\mathrm{mm}$; standard deviations and the number of foxes examined within parentheses.

\begin{tabular}{|l|c|c|c|c|c|}
\hline Foxes born in & 1966 & 1967 & 1968 & 1969 & 1970 \\
\hline Ages & $151.5(3.68 / 6)$ & $146.3(5.13 / 35)$ & $144.2(5.47 / 48)$ & $148.1(4.93 / 136)$ & $148.0(4.12 / 75)$ \\
\hline $0.00-1.26$ & $153.2(6.09 / 42)$ & $146.3(4.33 / 69)$ & $147.5(4.55 / 20)$ & $150.2(4.72 / 35)$ & $151.6(2.93 / 7)$ \\
\hline $1.27-2.26$ & $151.4(4.98 / 73)$ & $146.3(5.09 / 20)$ & $147.3(6.59 / 7)$ & $142.7(1.95 / 3)$ & - \\
\hline $2.27-3.26$ & $152.7(5.42 / 37)$ & $141.3(1.81 / 4)$ & $153.0(-/ 1)$ & - & $149.4(11.24 / 2)$ \\
\hline $3.27-4.26$ & $149.7(5.64 / 6)$ & - & - & - & $150.2(-/ 1)$ \\
\hline $4.27-$ & - & - & 2.3 & - & - \\
\hline Change/year & $>0.457$ & $>0.331$ & $<0.010$ & $>0.228$ & $>0.179$ \\
\hline p-value & - & - & 0.30 & - & - \\
\hline Correlation & - & - & 5.31 & - & - \\
\hline SE & & - & - & - & \\
\hline
\end{tabular}

Table 5. Age specific means of the condylobasal length in female foxes from the northern forest area in Sweden. Ages are given as years and the week numbers during which the foxes were killed. Means in mm; standard deviations and the number of foxes examined within parentheses.

\begin{tabular}{|l|c|c|c|c|c|}
\hline Foxes born in & 1966 & 1967 & 1968 & 1969 & 1970 \\
\hline Ages & $144.1(3.56 / 3)$ & $137.4(4.07 / 24)$ & $137.3(4.70 / 36)$ & $141.0(4.97 / 92)$ & $141.2(4.23 / 70)$ \\
\hline $0.00-1.26$ & $144.0(4.50 / 33)$ & $140.1(3.87 / 44)$ & $140.3(3.34 / 14)$ & $141.5(4.70 / 20)$ & $142.0(4.54 / 6)$ \\
\hline $1.27-2.26$ & $143.8(4.35 / 62)$ & $139.1(5.69 / 19)$ & $141.5(1.66 / 5)$ & $139.7(5.02 / 4)$ & $145.8(-/ 1)$ \\
\hline $2.27-3.26$ & $144.1(4.27 / 25)$ & $139.7(2.54 / 5)$ & - & $145.9(-/ 1)$ & - \\
\hline $3.27-4.26$ & $143.3(4.45 / 12)$ & $139.2(1.91 / 2)$ & - & - & - \\
\hline $4.27-$ & - & - & 2.5 & - & - \\
\hline Change/year & $>0.761$ & $>0.430$ & $<0.007$ & $>0.591$ & $>0.188$ \\
\hline p-value & - & - & 0.36 & - & - \\
\hline Correlation & - & - & 4.19 & - & - \\
\hline SE & - & & & - \\
\hline
\end{tabular}

foxes born in 1968 increased in size after their first year of life (Tab. 3 and Figs. 1 and 2). The width of the braincase and the mastoid, the length of $\mathrm{p} 1-\mathrm{p} 4, \mathrm{~m} 1-\mathrm{m} 3$ or the long bones did not increase with age, however. Most of the growth in adult foxes took place during their second summer in life (Tabs. 4-9).

\section{Discussion}

Small rodents constitute a very important food resource for foxes in the coniferous belt in northern Sweden, and there are very few alternatives when rodents are scarce (Englund, 1965). The number of cubs born after a winter when rodents are scarce is much lower than otherwise, and the cub mortality in the spring-summer period is very high (Englund, 1970, 1980 and Tab. 1).

This variation in food abundance also affects the growth rate in the first summer of life. Of the yearclasses studied here the 1966 cohort showed the best

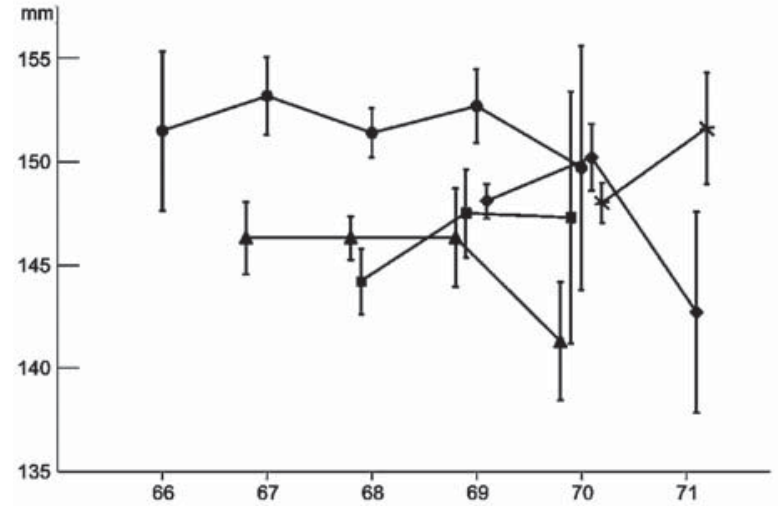

Figure 1. Size and continued growth of condylobasal length in male foxes born in different years (mean in $\mathrm{mm} \pm 95 \%$ confidence limits of the mean). Yearlings include foxes killed from January through June. Older ones include foxes killed all round the year (July 1 - June 30 ). 
Table 6. Age specific means of the zygomatic width in male foxes from the northern forest area in Sweden. Ages are given as years and the week numbers during which the foxes were killed. Means in $\mathrm{mm}$; standard deviations and the number of foxes examined within parentheses.

\begin{tabular}{|l|c|c|c|c|c|}
\hline Foxes born in & 1966 & 1967 & 1968 & 1969 & 1970 \\
\hline Ages & $80.7(1.99 / 8)$ & $78.6(2.44 / 31)$ & $78.3(2.40 / 31)$ & $79.7(2.52 / 115)$ & $79.2(2.35 / 57)$ \\
\hline $0.00-1.26$ & $82.7(2.70 / 41)$ & $81.0(2.32 / 69)$ & $82.1(2.99 / 20)$ & $82.3(1.79 / 35)$ & $80.3(1.91 / 9)$ \\
\hline $1.27-2.26$ & $82.7(2.48 / 63)$ & $82.6(2.89 / 21)$ & $83.3(2.30 / 7)$ & $81.1(0.60 / 3)$ & - \\
\hline $2.27-3.26$ & $83.4(2.98 / 37)$ & $79.9(1.34 / 4)$ & $84.8(-/ 1)$ & - & $86.0(-/ 1)$ \\
\hline $3.27-4.26$ & $82.7(3.48 / 8)$ & - & - & - & $83.2(-/ 1)$ \\
\hline $4.27-$ & - & 1.5 & 0.5 & 0.4 & 1.2 \\
\hline Change/year & $>0.069$ & $<0.001$ & $<0.001$ & $<0.001$ & $<0.004$ \\
\hline p-value & - & 0.41 & 0.60 & 0.39 & 0.35 \\
\hline Correlation & - & 2.51 & 2.69 & 2.39 & 2.32 \\
\hline SE & \multicolumn{7}{|c|}{-} & & & \\
\hline
\end{tabular}

Table 7. Age specific means of the zygomatic width in female foxes from the northern forest area in Sweden. Ages are given as years and the week numbers during which the foxes were killed. Means in mm; standard deviations and the number of foxes examined within parentheses.

\begin{tabular}{|l|c|c|c|c|c|}
\hline Foxes born in & 1966 & 1967 & 1968 & 1969 & 1970 \\
\hline \multicolumn{7}{|l|}{ Ages } & $77.3(0.42 / 2)$ & $74.8(2.54 / 23)$ & $74.8(1.97 / 26)$ & $75.0(2.28 / 93)$ & $74.4(2.07 / 58)$ \\
\hline $0.00-1.26$ & $77.5(2.55 / 34)$ & $77.1(2.35 / 48)$ & $77.2(2.16 / 13)$ & $76.4(3.12 / 17)$ & $77.0(2.23 / 6)$ \\
\hline $1.27-2.26$ & $78.1(2.31 / 58)$ & $77.0(2.33 / 21)$ & $79.2(2.50 / 5)$ & $77.0(1.53 / 4)$ & - \\
\hline $2.27-3.26$ & $78.1(1.91 / 26)$ & $76.3(1.83 / 6)$ & - & - & $75.6(-/ 1)$ \\
\hline $3.27-4.26$ & $78.2(1.90 / 12)$ & $78.3(2.64 / 3)$ & - & - & - \\
\hline $4.27-6.26$ & - & - & - & $78.5(-/ 1)$ & - \\
\hline $6.27-$ & - & 0.6 & 2.2 & 0.9 & - \\
\hline Change/year & $>0.262$ & $<0.012$ & $<0.001$ & $<0.008$ & $>0.067$ \\
\hline p-value & - & 0.25 & 0.59 & 0.25 & - \\
\hline Correlation & - & 2.35 & 2.09 & 2.43 & - \\
\hline SE & &
\end{tabular}

Table 8. Age specific means of the distance between $\mathrm{c}$ and $\mathrm{p} 1$ in the mandible in male foxes from the northern forest area in Sweden. Ages are given as years and the week numbers during which the foxes were killed. Means in mm; standard deviations and the number of foxes examined within parentheses.

\begin{tabular}{|l|c|c|c|c|c|}
\hline Foxes born in & 1966 & 1967 & 1968 & 1969 & 1970 \\
\hline Ages & \multicolumn{7}{|l|}{$\mid$} \\
\hline $0.00-1.26$ & $5.0(1.13 / 12)$ & $3.9(0.92 / 77)$ & $3.5(0.80 / 64)$ & $4.3(0.95 / 214)$ & $3.8(0.83 / 130)$ \\
\hline $1.27-2.26$ & $5.3(0.89 / 49)$ & $4.7(0.84 / 93)$ & $5.2(0.66 / 21)$ & $5.0(0.99 / 37)$ & $4.3(0.46 / 7)$ \\
\hline $2.27-3.26$ & $5.2(1.03 / 72)$ & $4.8(0.93 / 25)$ & $4.8(0.74 / 6)$ & $4.4(0.45 / 3)$ & - \\
\hline $3.27-4.26$ & $5.7(1.08 / 39)$ & $4.6(0.57 / 4)$ & $4.7(-/ 1)$ & - & $4.2(-/ 1)$ \\
\hline $4.27-$ & $6.0(1.01 / 9)$ & - & - & - & - \\
\hline Change/year & 0.2 & 0.5 & 0.9 & 0.5 & - \\
\hline p-value & $<0.009$ & $<0.001$ & $<0.001$ & $<0.001$ & $>0.211$ \\
\hline Correlation & 0.20 & 0.38 & 0.54 & 0.23 & - \\
\hline SE & 1.02 & 0.90 & 0.89 & 0.95 & - \\
\hline
\end{tabular}




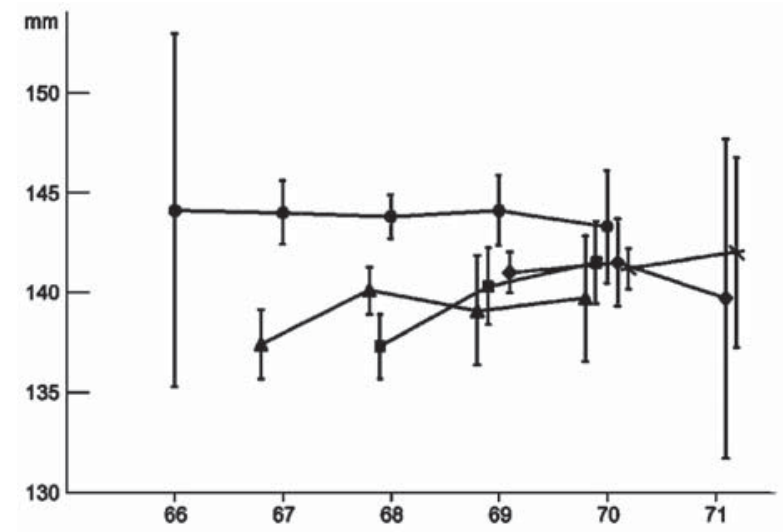

Figure 2. Size and continued growth of condylo-basal length in female foxes born in different years (mean in $\mathrm{mm} \pm 95 \%$ confidence limits of the mean). Yearlings include foxes killed from January through June. Older ones include foxes killed all round the year (July 1 - June 30 ).

growth and the smallest ones were born in 1967 and 1968.

1. The food availability in the summer of 1967 was extremely bad, resulting in a mortality rate among cubs which was double that of 1968, when the food situation was somewhat better. Still, the foxes from these two years did not differ in size (Tabs. 1 and 2). This needs an explanation.

In March-April 1967 rodents were extremely common which means that the pregnant vixens got enough of food with a high nutrition value (Englund, 1970, 1980). This may have affected the foeti positively. The vixens may also have had a good food situation in the spring and thus be able to produce plenty of milk for the suckling cubs. Due to lack of data from the spring period this assumption is unverified.

The following winter and the early spring of 1968 , the rodents were extremely rare resulting in a bad situation for the foeti as well as for the suckling cubs. In fact the shortage of food was so bad in early 1968 that the mean number of cubs born per vixen was only 0.8 as compared with 3.9 in 1967 (Englund, 1970, 1980).

The condition of the pregnant vixens as well as the food situation during both the suckling time and the first summer-autumn period of cub life therefore are supposed to affect the possibility for them to attain a good growth.

2. With the moderate increase of the rodent populations that started in the summer of 1968 , foxes born in 1969 and probably also those born in 1970 lived under a better food situation, and thus grew somewhat larger.

However, the mean for two variables, (the zygomatic width and the distance between $\mathrm{c}$ and $\mathrm{p} 1$ in the mandibles), was in four cases out of eight significantly larger among foxes born in 1967 than it was among foxes born in 1969 or 1970 . How can this be explained?

In contrast to the other measurements these two will increase in size during several years (Tabs. 3, 6-9). The combination of this and the fact that there are proportionally fewer old foxes in the material among those born in 1969 and 1970 is a possible explanation to this anomaly.

3. Adult foxes in southern Sweden have been shown to grow not only in their second summer in life, but also thereafter (Englund, 2006). The year-classes studied in the north deviate from this pattern in so far as only foxes born in 1968 grew as adults.

Why did foxes born in 1968 grow when one year old, while foxes born in 1966 and 1967 did not? And why did not these latter foxes grow in the summer of 1969 when foxes born in 1968 did (Tabs. 3-5 and Figs. 1 and 2)?

If adult foxes will get enough food of good quality, as the foxes in the north will in some years (or at least some summers), they will continue to grow. Out of the three summers of 1967 through 1969 only the latest one was good enough. This summer the rodents were rather common, and therefore foxes born in 1968 continued to grow.

Table 9. Age specific means of the distance between $\mathrm{c}$ and $\mathrm{p} 1$ in the mandible in female foxes from the northern forest area in Sweden. Ages are given as years and the week numbers during which the foxes were killed. Means in mm; standard deviations and the number of foxes examined within parentheses.

\begin{tabular}{|l|c|c|c|c|c|}
\hline Foxes born in & 1966 & 1967 & 1968 & 1969 & 1970 \\
\hline Ages & $4.7(0.67 / 5)$ & $3.4(0.83 / 63)$ & $3.3(0.75 / 55)$ & $4.0(0.82 / 142)$ & $3.6(0.90 / 106)$ \\
\hline $0.00-1.26$ & $4.8(0.85 / 51)$ & $4.1(0.73 / 58)$ & $4.4(0.72 / 20)$ & $4.6(0.83 / 29)$ & $4.0(1.00 / 6)$ \\
\hline $1.27-2.26$ & $5.0(0.89 / 66)$ & $4.9(1.00 / 23)$ & $5.1(0.81 / 4)$ & $5.3(0.45 / 3)$ & - \\
\hline $2.27-3.26$ & $5.0(0.88 / 29)$ & $4.9(0.72 / 6)$ & - & - & $3.7(-/ 1)$ \\
\hline $3.27-4.26$ & $4.9(0.76 / 8)$ & $4.9(-/ 1)$ & - & - & - \\
\hline $4.27-$ & - & 0.6 & 1.0 & 0.7 & - \\
\hline Change/year & $>0.419$ & $<0.001$ & $<0.001$ & $<0.001$ & $>0.334$ \\
\hline p-value & - & 0.54 & 0.60 & 0.34 & - \\
\hline Correlation & - & 0.83 & 0.75 & 0.82 & - \\
\hline SE & &
\end{tabular}


But if food was plentiful enough in the summer of 1969 for foxes born in 1968 to grow, why did not foxes born in 1966 or 1967 increase in size that summer? There may be two reasons for that. Adult foxes may demand more food to grow when $2+$ year old than during the second year of life. An alternative possibility may be the fact that older foxes more often have litters (Englund, $1970,1980)$ reducing the chance to feed themselves, and that this difference between ages may explain why one year old foxes grew in size but not the older ones.

4. Lindström (1983) supposed that foxes that were not full-grown in their first year of life due to food scarcity, compensated for that by growth later in life. This hypothesis is not supported by my data. Foxes studied here and born in 1967 did not compensate by further growth later in life. The growth during the second summer of life for foxes born in 1968 is just an ordinary growth among adults when food is plentiful enough, as it was in the summer of 1969 (Tabs. 3-5 and Figs. 1 and 2).

5. Yom-Tov et al. (2003) showed that the length of the upper P4 increased in length by $6.9 \%$ for Danish males and $7.2 \%$ for females during the twentieth century. During that period the amount of prey animals increased in number, among other species large ones as roe-deer and pheasants. Did the increase of the upper P4 was the result of a better growth of the young in the spring-summer period caused by the improved food situation as shown here (Tab. 2), or had the foxes changed genetically as an adaptation to larger prey Yom-Tov et al. (2003) ask?

In the agricultural counties of Uppland, Södermanland and Östergötland in southern Sweden the amount of food vary from year to year. In the spring-summer 1968 there were few rodents compared with 1966, 1967 and 1969, and foxes born in 1968 had significantly shorter upper P4. However, the difference in length was not greater than 0.9 and $1.0 \%$ for males and females respectively (own data). In northern Sweden the rodents were extremely common in the summer of 1966 and very few in 1967, and in this area there are few alternatives for foxes to eat. In spite of this extreme difference in food abundance, the length of the upper P4 did not differ more than $1.4 \%$ for males and $1.5 \%$ for females (Tab. 2).

Thus the increase in the length of the upper P4 for Danish foxes during the last century was much larger than the differences shown for Swedish foxes born in years with large difference in food amount. The main part of the increase of the upper P4 among the Danish foxes therefore is believed to be an adaptation to larger prey that increased in numbers during the twentieth century (Yom-Tov et al., 2003).

6. When food resources are reduced, the mean length of the cranium and the mandibles change more than other variables. The length of the long bones changes less and not for all groups. The mean widths of the braincase and the mastoid as well as the mean length of $\mathrm{P} 4, \mathrm{~m} 1$ and $\mathrm{m} 1-\mathrm{m} 3$ are only slightly affected by the amount of food (Tabs. 1 and 2).
This variation in change is probably caused by the fact that some bones can be reduced rather much without too large a change in the survival rate, while a reduction in other parts of the cranium, the mandibles or the skeleton is more likely to be of negative survival value.

That the length of the legs is important for a predator is easy to understand, especially for those living in areas with deep snow during a large part of the year as in the area studied. That the width of the braincase will be rather stable in size irrespective of environmental factors may also be easy to understand. A reduction in brain size may have severe effects and thus reduce the chance to survive.

A shortening in the length of the nose and the mandibles on the other hand seem to have less effect on survival rate than the other variables. These are the parts to be reduced to the greatest amount when food is scarce.

7. In subadult foxes born in years with low or moderate abundance of rodents, the mean zygomatic width as well as the mean distance between $\mathrm{c}$ and $\mathrm{p} 1$ is smaller than among foxes born under better food conditions (Tabs. 6-9). This reduction in mean size indicates that a full size of these structures is of less importance for the survival.

The further growth, which takes place in the adults even in years with food shortage, indicates the importance of full size for these structures later in life, however!

Can these two contradictory statements be incorporated in one theory? Out of 54 fox cubs tagged in years with high autumn rodent populations, and shot during the first autumn-winter period, $69 \%$ were killed within $5 \mathrm{~km}$ from the tagging place, and another 9\% were shot within $10 \mathrm{~km}$ (Englund, 1980). The corresponding figures for 1975, a year with rather few rodents, were 52 and $8 \%$ respectively for the 25 recoveries in the first autumn after tagging.

The conclusion from this is that a high proportion of the subadult foxes in these northern habitats do not leave their parents' territory during their first year of life. The high proportion of barren one year old vixens, even after winters with high numbers of rodents, supports this idea (Englund, 1970, 1980).

Later in life when foxes have to fight for own territories, however, it may be more important to be large to be successful in the social interactions. Thus a broad face may be very important. It is more difficult to understand why an increase in the c-p1 distance should increase the survival rate.

8. For some variables the differences of the means has been shown to vary with some few per cent for the year-classes studied. It may of course be questioned whether such small differences really will affect the survival rate or not. One should then not forget that a linear change in the length of some bones may have a rather prominent effect on the mass of the muscles involved. The changes thus are larger than it may look like at first.

ACKNOWLEDGMENTS. I wish to express my appreciation to all hunters who have made this investigation possi- 
ble by sending me the material. I also want to thank the late Professor N.-G. Gejwall at the Institute of Osteology at the University of Stockholm, for allowing me to use equipment in his Department for the automatic registering of measurements. I also want to thank A. Hanson for helping me with the boring job to measure all the fox skeletons and A. Bignert for producing the figures. Finally I would like to thank L. and F. Ôsterdahl for all valuable advice when writing the manuscript, and D. Johnston for correcting my English.

\section{References}

Billfors Ö. \& Jacobsen O. 1974. Automatic measurement and registration equipment for use with computers // Ossa. Vol.1. P.104.

Churcher Ch.S. 1960. Cranial variation in the North American red fox // Journal of Mammalogy. Vol.41. No.3. P.349-360.

Driesch A. von den. 1976. A guide to the measurement of animal bones from archaeological sites // Peabody Museum Bulletin. Vol.1. P.1-136.

Englund J. 1965. Studies on food ecology of the red fox (Vulpes vulpes) in Sweden // Viltrevy. Vol.3. No.4. P.377485.

Englund J. 1970. Some aspects of reproduction and mortality rates in Swedish foxes (Vulpes vulpes), 1961-63 and 1966-69 // Viltrevy. Vol.8. No.1. P.1-82.

Englund J. 1980. Population dynamics of the red fox (Vulpes vulpes L., 1758) in Sweden // Biogeographica. Vol.18. P.107-121.

Englund J. 2006. Cranial and skeletal growth patterns in red foxes (Vulpes vulpes L., 1758) // Russian Journal of Theriology. Vol.4. No.2. P.101-108.

Hell P., Paule L., Ševcenko L.S., Danko Š., Panigaj L. \& Vitaz V. 1989. Craniometrical investigation of the red fox (Vulpes vulpes) from the Slovak Carpathians and adjacent lowlands // Folia Zoologica. Vol.38. No.2. P.139-155.

Huson L.W. \& Page R.J.C. 1980. Age related variability in cranial measurements in the red fox (Vulpes vulpes) // Journal of Zoology. Vol.191. No.3. P.427-429.

Hörnfelt B. 1991. Cycles of Voles, Predators, and Alternative Prey in Boreal Sweden. PhD Thesis. Umeå University, Sweden.

Hörnfelt B. 1994. Delayed density dependence as a determinant of vole cycles // Ecology. Vol.75. No.3. P.791-806.

Jensen B. \& Nielsen L.B. 1968. Age determination in the red fox (Vulpes vulpes L.) from canine tooth sections // Danish Review of Game Biology. Vol.5. No.6. P.1-15.

Lindström E. 1983. Condition and growth of red foxes (Vulpes vulpes) in relation to food supply // Journal of Zoology. Vol.199. No.1. P.117-122.

Lloyd H.G. \& Englund J. 1973. The reproductive cycle of the red fox in Europe // Journal of Reproduction and Fertility, Supplement 19. P.119-130.

Lüps P. 1974. Wachstumsuntersuchungen an der Schädelbasis des Rotfuches (Vulpes vulpes L.) // Zoologische Jahrbücher, Abteilung für Anatomie und Ontogenie der Tiere. Bd.93. Hf.3. S.288-298.

Macdonald D.W. 1977. The Behavioural Ecology of the Red Fox, Vulpes vulpes; a Study of Social Organisation and Resource Exploitation. PhD Thesis. Oxford University. SPSS/PC+. Statistical Package for Social Sciences, Version 3.0. Chicago.

Yom-Tov Y., Yom-Tov S. \& Baagøe H. 2003. Increase of skull size in the red fox (Vulpes vulpes) and Eurasian badger (Meles meles) in Denmark during the twentieth century: an effect of improved diet? // Evolutionary Ecology Research. Vol.5. No.7. P.1037-1048. 